\title{
POSTAWA UBOGIEGO WOBEC OFIARODAWCY I JEGO DARU W NAUCZANIU STAROŻYTNEGO KOŚCIOLA (I-III WIEK)
}

Nierówny podział dóbr materialnych jest charakterystyczny nie tylko dla świata w XXI wieku. Również w starożytności, co poświadczają dostępne źródła, widoczny był wyraźny podział na ludzi bogatych, stanowiących niewielki procent ludności, i na całą rzeszę biedaków, którzy nie mieli możliwości, aby zaspokoić podstawowe potrzeby życiowe ${ }^{1}$. Rodzące się chrześcijaństwo nadaje działalności charytatywnej motywację religijna, mającą swe podstawy w nauczaniu Jezusa, który utożsamił się ze wszystkim potrzebującymi: „Wszystko, co uczyniliście jednemu z tych braci moich najmniejszych, Mnieście uczynili” (Mt 25, 40). Młody Kościół wypełnia to ewangeliczne przesłanie i otacza pomocą materialną ludzi ubogich, wpisując się tym samym także w starotestamentalną praktykę podejścia do ubogich, opartą na argumentacji religijnej ${ }^{2}$. Tak funkcjonuje pierwsza wspólnota jerozolimska, której członkowie oddają swój majątek do dyspozycji gminy; dzięki temu nikt nie cierpi tam biedy. Sw. Łukasz napisał: „Jeden duch i jedno serce ożywiały wszystkich wierzących. żaden nie nazywał swoim tego, co posiadał, ale wszystko mieli wspólne" (Dz 4, 32). Nie znaczy to, że wspólnota była idealna. Wystarczy wspomnieć postawę Ananiasza i Safiry (Dz 5, 1-10)․

Ojcowie Kościoła podejmując temat pomocy ubogim kierują swoje pouczenia przede wszystkim do ludzi bogatych. Tematyka ta była już wielokrotnie podejmowana $\mathrm{w}$ różnych opracowaniach ${ }^{4}$. Przedmiotem niniejszego artykułu

\footnotetext{
${ }^{1}$ Por. A. Rodziński, Sprawiedliwość chrześcijańska wobec problemu nierówności majątkowych w II i III wieku, Lublin 1960, 24.

${ }^{2}$ Por. D. Musiał, Asklepiejony jako ośrodki opieki nad chorymi w starożytności, VoxP 16 (1996) t. 30-31, 57-63; J. Homerski, Caritas w Starym Testamencie, VoxP 16 (1996) t. 30-31, 65-74.

${ }^{3}$ Por. A. Rodziński, Bogactwo i ubóstwo w świetle myśli chrześcijańskiej pierwszych trzech stuleci, VoxP 16 (1996) t. 30-31, 86.

${ }^{4}$ Por. J. Gliściński, Zagadnienia społeczne w pismach Ojców Kościoła, CT 63 (1993) 53-65; J. Grzywaczewski, Postawa dojrzałego chrześcijanina wobec skomplikowanych kwestii społecznych wedtug Klemensa Aleksandryjskiego, VoxP 10 (1990) t. 19, 651-657; J. Jundziłł, Czy człowiek bogaty może być zbawiony? Bogactwo i ubóstwo w świetle myśli patrystycznej, w: Patrystyczne
} 
jest natomiast przedstawienie i omówienie nauczania starożytnych duszpasterzy, skierowanego przede wszystkim do ludzi ubogich.

1. Odpowiedzialność ubogiego za otrzymany dar. Autorzy starochrześcijańscy dostrzegali problem zachowania ubogich wobec bogatych i ofiarowanego im daru. Już autor Didache przedstawił swoją refleksję na temat postawy ludzi proszących o jałmużnę. Według niego „szczęśliwy, kto daje zgodnie z przykazaniem, gdyż jest bez winy. Biada temu, kto bierze" ${ }^{5}$. Owo biada, które powtarza się również w Didaskaliach ${ }^{6}$, jest zwróceniem uwagi biorącemu jałmużnę, iż to on odpowiada za wyciagnięta rękę i za otrzymany dar. Nic mu nie grozi, jeśli wziął, ponieważ znajdował się w prawdziwej potrzebie. W takim przypadku ma prawo do wsparcia ze strony ludzi bogatych, czy też wspólnoty wierzących. Jeśli jednak nie cierpi niedostatku, a mimo to wyciagał rękę po wsparcie i przyjął je, odpowie przed sądem za swoje oszustwo. Będzie musiał nie tylko przyznać się do winy i wytłumaczyć się ze swojego czynu, ale nadto czeka go kara więzienia. Zostanie też zobowiązany do zwrotu wszystkiego, co niesłusznie sobie przywłaszczył, żerując na ludzkiej dobroci ${ }^{7}$. Autor Didache nie wyjaśnia, czy mówiąc o karze więzienia ma na myśli ziemski wymiar sprawiedliwości, czy też używa przenośni i mówi o karze czekającej oszusta w życiu wiecznym. Można sądzić, mając na uwadze kontekst wypowiedzi, przedstawiający zasady kroczenia „drogą życia”, że najpewniej chodzi mu jednak o sąd Boży. Wniosek taki jest tym bardziej uzasadniony, że w dalszej części dzieła postawy chciwości i pożądliwości, które uzewnętrzniły się w wyciągniętych rękach oszusta, zostały umieszczone w katalogu grzechów prowadzących człowieka „drogą śmierci”». Tym niemniej nie można wykluczyć dosłownej interpretacji tego fragmentu Didache.

Także w Didaskaliach odnajdziemy przemyślenia dotyczące nieusprawiedliwionego wyciągania rąk po wsparcie. Autor tego zbioru podkreśla, iż zło takiej postawy polega nie tylko na wyłudzaniu datków. Oszuści biorąc to, co im się nie należy, uszczuplają w ten sposób ,zasoby przeznaczone dla wiernych naprawdę potrzebujących"". Są zatem złodziejami, gdyż przywłaszczyli sobie dobra przeznaczone dla prawdziwie ubogich. W dniu sądu odpowiedzą nie tylko za lenistwo, nieuczciwość i kradzieże, ale także za niewiarę. Wyłu-

dziedzictwo społecznej nauki Kościoła, red. T. Makowski, Gniezno 1996, 31-40; W. Myszor, Europa. Pierwotne chrześcijaństwo, Warszawa 1999-2000, 233-244.

${ }^{5}$ Didache 1, 5, cytowane w: Constitutiones Apostolorum VII 2, 4, tłum. A. Baron, ŹMT 42 , Kraków 2007, 175*.

${ }^{6}$ Por. Didascalia IV 3, ed. F.X Funk: Didascalia et Constitutiones Apostolorum, I, Paderborn 1905, 220.

${ }^{7}$ Por. Didache 1, 5; Constitutiones Apostolorum VII 2, 4, ŹMT 42, 175.

${ }^{8}$ Por. Didache 5, 2; Constitutiones Apostolorum VII 18, 1, ŹMT 42, 183.

${ }^{9}$ Didascalia IV 3, ed. Funk I 220, tłum. M. Michalski, Antologia literatury patrystycznej, I, Warszawa 1975, 328. 
dzając bowiem jałmużnę i gromadząc sobie dobra, do których nie mają prawa, poświadczają, że nie potrafią zaufać Bogu ${ }^{10}$.

Takie nieuczciwe postawy ludzi, którzy wyłudzali jałmużnę, mogły budzić w ofiarodawcach zniechęcenie i poczucie człowieka oszukanego i wykorzystanego. $Z$ tego powodu autor Didache zaleca wiernym, aby jałmużna spociła się w ręku ofiarodawcy, zanim pozna, komu ją dać ${ }^{11}$; a zatem człowiek, który jest pełen szczerego współodczuwania z biednymi, nie może zapominać o roztropności i przezorności $\mathrm{w}$ udzielaniu jałmużny ${ }^{12}$. Trzeba jednak przyznać, iż taka postawa, wydawałoby się usprawiedliwionej ostrożności ofiarodawcy, może mieć też negatywne skutki i prowadzić do zbyt pochopnego osądzania ludzi proszących o wsparcie. $Z$ pewnością dlatego Hermas zachęcając wiernych do postawy prostoty prosi, aby dzielili się owocami swojej pracy ze wszystkim potrzebującymi ,nie roztrząsając, komu dać, a komu nie dawać”"13. Należy bowiem być przekonanym, że wolą samego Boga jest pomoc biednym. Dobroczyńca musi sobie zdawać sprawę, że ostatecznie nie daje ze swojego, ale dzieli się Bożymi darami ${ }^{14}$. Również Klemens Aleksandryjski uważa, że ofiarodawcy nie powinni zajmować się osądzaniem intencji proszących o jałmużnę. Aleksandryjczyk zachęca więc swoich słuchaczy:

„Nie rozstrzygaj, kto jest godny, a kto niegodziwy: możesz się bowiem w sądzie swym pomylić. W tej niepewności płynącej z niewiedzy lepiej jest nawet ludziom niegodnym czynić dobrze pamiętając o tych, którzy są godni, niż wystrzegając się mniej cnotliwych pominąc ludzi zacnych"15.

To bardzo cenna i ciekawa propozycja. Aleksandryjczyk zdaje sobie sprawę, iż ludzie w swoich sądach nie bywają obiektywni i najczęściej kierują się pierwszym wrażeniem oraz emocjami. Jest więc możliwa pomyłka i błędna ocena prowadząca niejednokrotnie do błędnego osądu nawet „przyjaciół Boga”. Klemens radzi zatem, aby rozdawać dobra wszystkim proszącym, gdyż wśród nich są najpewniej również ci, którzy prawdziwie potrzebują wsparcia ${ }^{16}$. Również Tertulian ukazując w Apologetyku charytatywną postawę chrześcijan zapewnia, że ofiarują oni pomoc każdemu, kto prosi ${ }^{17}$. W ten sposób prezentuje poganom caritas chrześcijan, która jest wrażliwa na potrzeby każdego człowieka.

\footnotetext{
${ }^{10}$ Por. Didascalia IV 3, ed. Funk I 220.

${ }^{11}$ Por. Didache 1, 6; Constitutiones Apostolorum VII 2, 12, ŹMT 42, 176.

${ }^{12}$ Por. Rodziński, Bogactwo i ubóstwo, s. 88; tenże, Sprawiedliwość chrześcijańska, s. 110.

${ }^{13}$ Hermas, Pastor. Mand. II 27, 4, SCh 53bis, 146-148, tłum. A. Świderkówna, BOK 10, Kraków 1998, 229.

${ }^{14}$ Por. tamże.

${ }^{15}$ Clemens Alexandrinus, Quis dives salvetur 33, 2, GCS 17, 181, thum. J. Czuj, MBOK 2, Kraków 2012, 98-99; por. Rodziński, Sprawiedliwość chrześcijańska, s. 110-111.

${ }^{16}$ Por. Clemens Alexandrinus, Quis dives salvetur 33, 2, GCS 17, 181, MBOK 2, 99.

${ }^{17}$ Por. Tertullianus, Apologeticus 42, CSEL 69, 100-102, thum. J. Sajdak, POK 20, 174; por. K. Obrycki, Problematyka charytatywna w pismach Tertuliana, VoxP 16 (1996) t. 30-31, 94.
} 
Autorzy starochrześcijańscy nie mieli wątpliwości, komu należy pomagać. W Didaskaliach wymienia się osoby, które mają prawo do jałmużny ${ }^{18}$, a są to: dzieci - sieroty, niedołężni starcy, ludzie ciężko chorzy oraz wielodzietne rodziny: wszyscy oni są godni wsparcia, gdyż jako prawdziwie ubodzy stanowią jakby ołtarz, na którym bogaty składa Bogu swoją ofiarę ${ }^{19}$. Jest to bardzo piękne, a w swej treści wiele mówiące i głęboko teologiczne porównanie. Metafora ta znana już wcześniej używana była m.in. przez Polikarpa ze Smyrny w odniesieniu do wdów, które otaczane były szczególnym wsparciem przez wspólnotę wierzących ${ }^{20}$. Przyjęcie takiej terminologii wyraźnie podkreśla nadprzyrodzony charakter jałmużny. Wsparcie ubogiego jest więc aktem miłości ofiarowanej samemu Bogu. Jednocześnie ubogi, często poniżany, poniewierany w społeczeństwie i obdzierany z ludzkiej godności, zostaje tu ukazany jako człowiek szczególnie wybrany: jest ołtarzem, na którym można złożyć ofiarę samemu Bogu. Myśl ta dowodzi, jak bardzo Kościół od samego początku swego istnienia akcentował godność każdego człowieka, niezależnie od jego statusu majątkowego. Była to w Imperium nowa kategoria podejścia do człowieka. Z zasady bowiem liczono się przede wszystkim z ludźmi majętnymi, spychając biednych na margines życia społecznego.

Ofiarodawca nie powinien też dociekać, co przyjmujący jałmużnę człowiek z nią zrobi. Wszak, jak zauważa to Hermas, dobroczyńca wypełnia jedynie posługę zleconą przez Boga. Bogaty dając z prostoty serca, nawet jeśli da się oszukać, nie zaciąga żadnej winy i nie będzie nigdy z tego sądzony. Przeciwnie, czyn taki będzie mu policzony jako chwalebny. Natomiast „ci, którzy oszukiwali po to, aby brać, poniosą karę"21. Zgodnie bowiem z powszechnym przekonaniem, odpowiedzą oni przed Panem za popełnioną nieuczciwość.

Obawy przed oszustwem, jak również troska, aby pomoc dotarła do osób najbardziej potrzebujących, zaowocowały wypracowaniem przez Kościół praktyki wspierania ubogich za pośrednictwem przewodniczącego gminy. To do jego obowiązków, jak pisze Justyn czy też Didaskalia, należała opieka nad wszystkimi potrzebującymi ${ }^{22}$. To on ma rozdzielać dary ofiarowane przez wspólnotę ludziom, o których jako pasterz wie, że są w prawdziwej potrzebie. A. Rodziński zauważa ponadto, że ten sposób rozdzielania jałmużny chronił ubogich przed poniżeniem i poczuciem zależności od bogatych, a ofiarodawców tak przed nieuczciwością biorących, jak i pokusą pychy i samozadowolenia ${ }^{23}$.

${ }^{18}$ Św. Justyn w swojej Apologii przedstawił również listę osób mających prawo do opieki ze strony wspólnoty wierzących. Lista ta obejmuje także wdowy, więźniów, obcych, gości oraz wszystkich cierpiących niedostatek, por. Justinus, Apologia I 67, 6, PG 6, 429-430.

${ }^{19}$ Por. Didascalia IV 3, ed. Funk I 220.

${ }^{20}$ Por. Policarpus, Epistula ad Philippenses 4, 3, SCh 10, 182; zob. A. Hamman, Życie codzienne pierwszych chrześcijan (95-197), thum. A. Guryn - U. Suchodolska, Warszawa 1990, 201.

${ }^{21}$ Hermas, Pastor. Mand. II 27, 5-6, SCh 53bis, 148. BOK 10, 229.

${ }^{22}$ Por. Justinus, Apologia I 67, PG 6, 429-430; Didascalia IV 5, ed. Funk I 222.

${ }^{23}$ Por. Rodziński, Bogactwo i ubóstwo, s. 88; tenże, Sprawiedliwość chrześcijańska, s. 111. 
Autorzy starochrześcijańscy zwracają również uwagę na bardzo istotny wymóg stawiany ludziom potrzebującym: nie wolno im przyjmować wsparcia od każdego człowieka. W Didaskaliach przestrzega się więc przed przyjmowaniem darów od ludzi niegodnych:

„Gdy bowiem wdowa żywi się suchym chlebem z daru uczciwości, wyjdzie jej na pożytek: gdy zaś wiele jej dadzą z dzieł niegodziwości, będzie jej ku szkodzie"24.

Lepiej więc mieć mało, ale z uczciwego źródła, aniżeli wiele, od niegodnego dawcy. Tylko dar z godziwego źródła przynosi biedakowi prawdziwy pożytek. Wydaje się więc, że domagano się od biednych sprawdzenia, czy wspierający ich ludzie są prawymi członkami Kościoła. Taka weryfikacja ofiarodawców była możliwa jedynie w małych gminach, w których wierni wzajemnie się znali.

Także biskup, organizujący pomoc dla ubogich swojej wspólnoty, został zobowiązany do bardzo skrupulatnego zwracania uwagi ,nie tylko na to, co ktoś daje, ale również na to, kim jest sam dający lub dająca"25. Nie mógł zatem pasterz gminy przyjmować darów od publicznych grzeszników, to znaczy:

„od bogaczy, którzy bliźnich zamykają w więzieniu, źle traktują niewolników, tyranię stosują w swych miastach, gnębią biedaków; od nikczemników i ludzi co ciała swe haniebnie nadużywają; od przestępców, wreszcie do fałszerzy, od nieuczciwych adwokatów, kłamliwych oskarżycieli, stronniczych sędziów, malarzy i rzeźbiarzy bożków pogańskich, złodziejskich jubilerów, niesumiennych celników, jasnowidzów, fałszerzy wag i miar, szynkarzy dolewających wody, żołnierzy wywołujących burdy, morderców sądowych, a także wszystkich urzędników rzymskich, splamionych wojnami i przelewających bez sądu krew niewinną [...] od bałwochwalców, od nieczystych, od takich, co wymuszają opłaty i uprawiają lichwę"26.

Przedstawiona lista obejmuje szeroki krag ludzi, wśród których są nie tylko ludzie nieuczciwi, wiodący życie niemoralne, ale również odstępcy od wiary, oddający cześć bóstwom pogańskim.

W Kościele starożytnym obowiązywał także całkowity zakaz przyjmowania pomocy od wiernych, którzy nie są w pełnej jedności z Kościołem ${ }^{27}$. Zakaz ten stał się powszechną praktyką Kościoła usankcjonowaną przez uchwały synodalne. Przykładem takich postanowień jest treść kanonu 28 przyjętego przez uczestników synodu w Elwirze (ok. 306), którzy uchwalili, że:

${ }^{24}$ Didascalia IV 6, ed. Funk I 226, ALP I 329; por. Rodziński, Sprawiedliwość chrześcijańska, s. 72.

${ }^{25}$ Didascalia IV 3, ed. Funk I 220, ALP I 329.

${ }^{26}$ Tamże IV 6, ed. Funk I 226, ALP I 329.

${ }^{27}$ Por. tamże IV 8, ed. Funk I 228. 
„biskup nie powinien przyjmować darów od tych, którzy nie przystępują do komunii" 28 .

Także Konstytucje Apostolskie poświęciły tej kwestii sporo miejsca. Zapisane w nich zasady są bardzo radykalne:

„Lepiej nawet zginąć, niż przyjać cokolwiek od wrogów Boga”29.

Trzeba przyznać, że tak surowe i wymagające stanowisko Kościoła wymagało od biedaków postaw być może nawet heroicznych, tym bardziej gdy chodziło o wsparcie dla licznej rodziny. Należy jednak rozumieć tak radykalną postawę ówczesnych duszpasterzy, którzy przyjmując tak jednoznaczne reguły, wypływające z ducha Ewangelii, chcieli uczyć wiernych, jak ważna jest wierność słowu Bożemu oraz uczciwość i prostota w życiu chrześcijanina.

Należy jeszcze wspomnieć o omówionym w Didaskaliach przypadku zmuszania ubogiego lub też biskupa do przyjęcia jałmużny od człowieka nieuczciwego. W tej sytuacji rodził się problem, co zrobić z taką ofiarą. Zaproponowane rozwiązanie może zadziwić współczesnego czytelnika: otóż $\mathrm{w}$ omawianym przypadku biskup powinien wszystkie otrzymane z nieuczciwego źródła środki przeznaczyć na opał mieszkań wdów i sierot. W ten sposób pieniądze pochodzące $\mathrm{z}$ nieuczciwości były pośrednio spalone. Jednocześnie kategorycznie zabraniano przeznaczania takich środków na jakikolwiek inny cel, np. na jedzenie ${ }^{30}$. Jak zauważa A. Hamman, Kościół odrzuca w ten sposób wszelkie ofiary pochodzące czy to z nieuczciwego zarobku, czy też z dochodów uzyskanych z wykonywania niegodziwego zawodu ${ }^{31}$. Taka czytelna postawa Kościoła była ważna w wychowywaniu społeczeństwa do uczciwości i kształtowania $\mathrm{w}$ wiernych właściwej hierarchii wartości. Ludzie bogaci, którzy zdobyli swój majątek w sposób nieuczciwy, lub żerując na ludzkiej krzywdzie, doświadczając takiej postawy Kościoła musieli przyjąć prawdę, że za pieniądze nie można kupić wszystkiego, a z całą pewnością zbawienia. Aby je osiagnąć, konieczne jest najpierw nawrócenie i wypełnienie przypisanej pokuty. Ubodzy zaś, dzięki tak jednoznacznej nauce Kościoła o konieczności zachowania uczciwości w każdej sytuacji życiowej, mieli nadzieję, że będą wysłuchani w modlitwie. Byli bowiem przekonani, że człowiek - Didaskalia mówią o wdowach - wiedząc o nieuczciwym pochodzeniu otrzymanych dóbr, nie mógł z czystym sercem zanosić prośby do Boga. Modlitwa w intencji nieuczciwego ofiarodawcy z pewnością nie będzie wysłuchana; co najwyżej Bóg przyjmie modlitwę we własnej intencji ${ }^{32}$. Przewodniczący gminy i wszyscy zajmujący się realizacją caritas chrześcijańskiej przyjmując tak radykalną po-

\footnotetext{
${ }^{28}$ Por. Concilium Eliberitanum can. 28, ŹMT 37 (= Synody i Kolekcje Praw I), 54.

${ }^{29}$ Constitutiones Apostolorum IV 8, 2, ŹMT 42 (= Synody i Kolekcje Praw II), 102.

${ }^{30}$ Por. Didascalia IV 10, ed. Funk I 230.

${ }^{31}$ Por. Hamman, Życie codzienne pierwszych chrześcijan, s. 216.

${ }^{32}$ Por. Didascalia IV 7, ed. Funk I 226.
} 
stawę wobec podejrzanych ofiarodawców sami unikali uwikłania się w grzechy nieuczciwości ${ }^{33}$.

2. Wzajemna zależność darczyńcy i obdarowanego. Ojcowie Kościoła uświadamiają swoim słuchaczom i czytelnikom, że ubogi przyjmując dar od bogatego, nigdy nie pozostaje jego dłużnikiem. Jak to możliwe, bardzo dokładnie wyjaśnia Hermas w przypowieści o wiązie i winorośli ${ }^{34}$. Wiąz, jak niekiedy uważano w starożytności, jest drzewem bezpłodnym, ponieważ nie rodzi żadnych owoców. Jest więc drzewem całkowicie bezużytecznym. Zupełnie inaczej ma się rzecz z winoroślą, która rodzi owoce. Aby jednak grona były dorodne, winorośl musi się po czymś wspinać. Za podporę do wzrostu winorośli może służyć wiąz. Dzięki temu - konkluduje Hermas - „kiedy winorośl połączy się z wiązem, wydaje owoce i za wiąz i za siebie samą" ${ }^{35}$. Przypowieść o wiązie $\mathrm{i}$ winorośli oraz o ich symbiozie jest metaforą, która mówi o bogatych i biednych. W ten sposób Hermas pragnie zachęcić wiernych, aby żyli w symbiozie pomagając sobie wzajemnie. Bogaci, którzy są zabiegani w sprawach tego świata, nie poświęcają modlitwie tyle czasu i uwagi, ile powinni. Ich modlitwy są ,krótkie, słabe i pozbawione jakiekolwiek mocy”36; są zatem duchowo ubodzy, ale bogaci materialnie. Biedacy natomiast, choć są ubodzy materialnie, to jednak równocześnie są bogaci duchowo. Ich bogactwo duchowe jest owocem rozwiniętego życia wiary. A zatem, kiedy bogaci wspierają biednych swoimi jałmużnami, dbając, aby mieli wszystko, co do życia jest koniecznie potrzebne, w zamian otrzymują dar modlitwy wstawienniczej ${ }^{37}$ :

„Biedak obdarzony przez bogatego dziękując Bogu modli się do Niego za swego dobroczyńcę, a tamten coraz gorliwiej troszczy się o biedaka" ${ }^{" 38}$.

W ten sposób pomiędzy zamożnym ofiarodawcą i obdarowanym biedakiem wytwarza się relacja wymiany dóbr - materialnych i duchowych. Przy czym bogaty powinien być świadomy, że nie daje ze swojego, gdyż posiadane przez niego bogactwo jest Bożym darem, danym mu do zarządzania i umiejętnego dysponowania ${ }^{39}$. W tej wzajemnej wymianie, bogaty zyskuje więcej. Przekonuje o tym swoich słuchaczy Klemens Aleksandryjski:

„O jakiż to zysk piękny! Jakaż boska zamiana! Za mienie swoje możesz

${ }^{33}$ Por. tamże IV 10, ed. Funk I 230.

${ }^{34}$ Klemens Aleksandryjski przytacza również tę przypowieść, ale objaśnia ją inaczej aniżeli Hermas, por. Clemens Alexandrinus, Stromata VI 15, GCS 52, 490-491.

${ }^{35}$ Hermas, Pastor. Sim. II 51, 1-4, SCh 53bis, 214-217, BOK 10, 249.

${ }^{36}$ Tamże Sim. II 51, 5, SCh 53bis, 216-217, BOK 10, 249-250.

${ }^{37}$ Por. tamże Sim. V 56, 7, SCh 53bis, 232, BOK 10, 254.

${ }^{38}$ Tamże Sim. IV 53, 6, SCh 53bis, 222, BOK 10, 250.

${ }^{39}$ Por. Clemens Alexandrinus, Quis dives salvetur 14, GCS 17, 168-169. 
nabyć nieśmiertelność, a oddając znikome dobra światowe otrzymać za nie w zamian wieczne mieszkanie w niebie" ${ }^{" 40}$.

Zatem to, co nietrwałe i przemijające, można zamienić na dobra wieczne. Jest to możliwe, ponieważ biedny wyobraża samego Boga. Aleksandryjczyk zachęca w związku z tym swoich bogatych słuchaczy, aby wzbudzili w sobie pragnienie Królestwa Bożego. Jeśli motywowani tak pięknym pragnieniem będą wspierali biednych, to każdy obdarowany biedak, który „tu na ziemi niewiele [...] weźmie, [...] sprawi, że tam przez całą wieczność z Nim razem będziesz mieszkać"41. Dalsza część wypowiedzi Aleksandryjczyka brzmi wręcz paradoksalnie, gdyż zaprzecza powszechnemu przekonaniu, że pozycję proszącego zajmuje zawsze biedak. Okazuje się, że według Klemensa proszącym jest bogaty. Jest to zrozumiałe, ponieważ dobra wieczne są nieporównywalnie bardziej wartościowe aniżeli dobra doczesne. Zatem to bogacz musi prosić ubogiego, aby ten zechciał od niego wziąć. Aleksandryjczyk zachęca bogatych:

„Błagaj, by wziął, staraj się i trudź, lękaj się, by ci nie odmówił przyjęcia.

Chrystus bowiem nikomu brać nie nakazał, ale tobie polecił dawać" ${ }^{42}$.

W ten sposób przyjęte powszechnie w porządku światowym role biedaka i bogatego - biedak prosi bogatego - odwracają się. Bowiem w kategoriach wartości duchowych, to bogaty musi prosić biednego, aby ten wziął od niego dar materialny i w ten sposób otworzył mu drogę do królestwa Bożego. Należy podkreślić, że przedstawiona przez Klemensa myśl, ma szansę na realizację w codziennym życiu tylko wówczas, kiedy i bogaty i biedny będą wolni od pożądania dóbr materialnych, i jeśli królestwo Boże będzie dla nich najwyższą wartością. Byłaby to sytuacja idealna, która w codziennej szarości życia jest niestety trudna do osiagnnięcia. Warto jednak zauważyć, że w ten sposób w Kościele starożytnym powstaje tradycja wzajemnej wymiany dóbr pomiędzy bogatymi i biednymi, która jest realizowana aż po dzień dzisiejszy.

We wzajemnej wymianie dóbr biedni obdarzają swoich ofiarodawców modlitwą wstawienniczą. Klemens Rzymski zalecając wiernym z Koryntu, aby wzajemnie się wspomagali, biedni i bogaci, zaprasza ubogich członków tamtejszej gminy do dziękowania Bogu, że „dał mu kogoś, kto może zaspokoić jego potrzeby" ${ }^{\prime 3}$. W ten sposób biskup Rzymu precyzuje intencję modlitwy biedaków. Ma to być modlitwa dziękczynna, skierowana do Boga. On bowiem jest sprawcą wszelkiego dobra, On więc zatroszczył się o ubogiego poprzez dary bogatego. $\mathrm{Z}$ drugiej strony bogaci czytając te słowa, mogli uświadomić

${ }^{40}$ Tamże 32, GCS 17, 181, MBOK 2, 97.

${ }^{41}$ Hermas, Pastor. Sim. II 51, 7, SCh 53bis, 216, BOK 10, 250.

${ }^{42}$ Clemens Alexandrinus, Quis dives salvetur 32, GCS 17, 181, MBOK 2, 97.

${ }^{43}$ Clemens Romanus, Epistula ad Corinthios 38, 2, SCh 167, 162, tłum. A. Świderkówna, BOK 10, Kraków 1998, 68. 
sobie, że dzieląc się posiadanym przez siebie majątkiem, zostają obdarzeni wyjątkową godnością - stają się narzędziem w rękach samego Boga.

Należy jeszcze zauważyć, że wdzięczność biednych wykracza poza czas życia wspierających ich ludzi bogatych. Przykładem takiej postawy, jak zauważa to św. Cyprian, jest opisane w Dziejach Apostolskich zachowanie wdów po śmierci Tabity (por. Dz 9, 36-41). Kobiety te zrozpaczone śmiercia swojej dobrodziejki pokazywały Piotrowi jak wiele dla nich zrobiła. I choć św. Łukasz nie wspomina ani słowem o modlitwie wdów, to biskup Kartaginy z przekonaniem napisał, ,że wdowom błagającym nie braknie pomocy Chrystusa, skoro on sam otaczał wdowy opieką"44. Poproszony o modlitwę Piotr prosi Boga w imię Jezusa Chrystusa za Tabitą. Modlitwa została wysłuchana i Tabita wróciła do życia. Wskrzeszenie dobrodziejki tak wielu osób było zdaniem biskupa Kartaginy możliwe przede wszystkim dzięki jej pięknemu życiu, gdyż ,tak wiele mogły zasługi miłosierdzia, tak wiele znaczyły sprawiedliwe uczynki”"45. Zauważa jednak Cyprian, że ważne były również modlitwy wdów:

„Ta, która wdowom w biedzie będącym, hojnie dawała środki do życia, zasłużyła przy pomocy wdowich próśb na powrót do życia" ${ }^{46}$.

Modlitwa wdów była więc wyrazem wdzięczności wobec Tabity, ale i znakiem głębokiej wiary w Boże miłosierdzie. Modlitwa biednych w intencji ofiarodawców wyrasta zatem z wiary w potęgę Bożej Opatrzności, która objawiła się dobrocią bogatych ludzi, a także z poczucia wdzięczności za wszelkie otrzymane dobra.

W podsumowaniu powyższych rozważań trzeba stwierdzić:

1. Każdy ubogi proszący bogatych o wsparcie, jest odpowiedzialny przed Bogiem za otrzymany dar. Wszyscy, którzy wykorzystują dobroć ludzi bogatych i wyłudzają od nich pomoc będą odpowiadali przed Bożym sądem.

2. Ubogi znajdujący się $\mathrm{w}$ prawdziwej potrzebie stanowi ołtarz Boży. Podarowana mu jałmużna jest ofiara, którą bogaty składa na ołtarzu samego Boga. Dzięki temu jałmużna otrzymuje wymiar nadprzyrodzony.

3. Pomiędzy ofiarodawcą i obdarowanym tworzy się relacja wzajemnej wymiany dóbr. Ubogi wspierany dobrami materialnymi przez bogatego odwzajemnia się darami duchowymi: modlitwą wstawienniczą i wdzięcznością trwającą także po śmierci dobroczyńcy.

4. Bogaty obdarowany dobrami duchowymi zyskuje więcej, aniżeli ubogi,

${ }^{44}$ Cyprianus Carthaginiensis, De opere et eleemosynis 6, CSEL 3/1, 378, thum. J. Czuj, POK 19, Poznań 1937, 331.

${ }^{45}$ Tamże.

${ }^{46}$ Tamże 6, CSEL 3/1, 378, POK 19, 331-332. 
gdyż za nietrwałe dobra materialne, które otrzymał w zarząd od Boga, otrzymuje dobra wieczne, czyli udział w Królestwie niebieskim.

\section{THE ATTITUDE OF A POOR PERSON TO THE BENEFACTOR AND HIS GIFT IN THE TEACHING OF THE ANCIENT CHURCH (1 $1^{\mathrm{ST}}-3^{\mathrm{RD}}$ CENTURY)}

(Summary)

The article deals with the problem of the responsibility of a poor person for the received gift. Analysis of selected writings of Christian antiquity reveals that every poor person who asks the rich for assistance is responsible to God for the received gift. All those who appeal to the benevolence of the rich and extort their help will answer at God's judgment. In turn a poor person who is in real need is God's altar. The alms given to the poor are a sacrifice that the rich offer on the altar of God himself. This confers a supernatural dimension upon alms. Moreover, between the benefactor and the recipient the relation of a reciprocal exchange of goods is established. The poor person who is supported with material goods by a rich person reciprocates with spiritual gifts: intercessory prayer and gratitude that continue even after the benefactor's death. Thus, the rich person who receives the spiritual gifts benefits more than the poor person because in return for perishable material goods he is given eternal life. 